University of Nebraska - Lincoln

DigitalCommons@University of Nebraska - Lincoln

Public Health Resources

Public Health Resources

4-1972

\title{
Surveillance of Legal Abortions in the United States, 1970
}

Judith Bourne

Center for Disease Control, Atlanta

James Kahn

Center for Disease Control

S. Beach Conger

University of California

Carl Tyler Jr.

Center for Disease Control, Atlanta

Follow this and additional works at: https://digitalcommons.unl.edu/publichealthresources

Part of the Public Health Commons

Bourne, Judith; Kahn, James; Beach Conger, S.; and Tyler, Carl Jr., "Surveillance of Legal Abortions in the United States, 1970" (1972). Public Health Resources. 237.

https://digitalcommons.unl.edu/publichealthresources/237

This Article is brought to you for free and open access by the Public Health Resources at DigitalCommons@University of Nebraska - Lincoln. It has been accepted for inclusion in Public Health Resources by an authorized administrator of DigitalCommons@University of Nebraska - Lincoln. 
Pilot Issue, April 1972

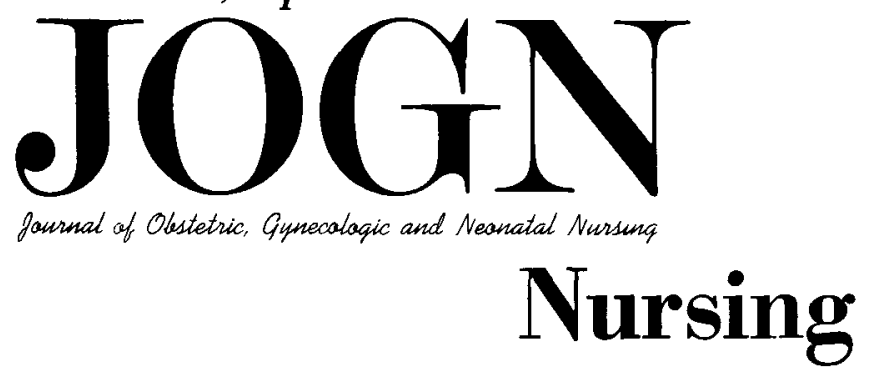

Journal of The Nurses Association

of The American College of

Obstetricians and Gynecologists

\section{Surveillance of Legal Abortions in the United States, 1970}

JUDITH P. BOURNE, RN, MS

JAMES B. KAHN, MD

S. BEACH CONGER, $M D$ and

CARL W. TYLER, JR, MD

In 1969, a series of epidemiologic studies for abortion in the United States was begun at the Center for Disease Control (CDC) in Atlanta, Georgia. Unwanted pregnancy is one of the most prevalent and potent public bealth problems in this and many other countries, and in almost all societies abortion is an inevitable concomitant of unwanted pregnancies.

In 1970 we concentrated primarily on three aspects of the rapidly changing phenomenon of abortion in the United States, attempting first to ascertain how many legal abortions are performed and where they are performed; second to describe the population of women who obtain legal abortion, and third to identify factors associated with morbidity and mortality resulting from induced abortion in this country.

Preliminary to any success in our effort to obtain an accurate case count of legal abortions, it was necessary to study abortion law and abortion reporting systems in each state. Table 1 lists each state in one of eight categories on the basis of major legal requirements for performance of abortion in that state, as of the end of 1970 .

Funded in part through the Center for Population Research, National Institute of Child Health and Human Development,

National Institute of Health, Bethesda, Maryland.

From the US Department of Health, Education, and Welfare

Public Health Service, Health Services and Mental Health

Administration, Center for Disease Control,

Atlanta, Georgia 30333.
Twenty-eight states in Category 1 have laws that prohibit abortion except when necessary to preserve the mother's life. Mississippi, the only state in Category 2, allows abortion to preserve the woman's life or when pregnancy has resulted from rape. The District of Columbia and 21 states in Categories 3 through 8 all have laws which allow abortions to be performed under a broader range of circumstances. Four states in Categories 3 and 4 (Massachusetts, New Jersey, Pennsylvania and Alabama) have abortion laws worded in broad or vague terms which can be interpreted to permit abortion in situations that do not threaten the woman's life. States in Categories 5, 6, and 7 allow abortions in a variety of circumstances in accordance with new abortion laws enacted after January 1967. Category 8 includes the District of Columbia and three states that had their abortion laws substantially altered or completely invalidated by Federal District Court decisions rendered prior to the end of 1970 . Not shown in Table 1 are changes in the status of 
I. Abortion allowed only when necessary to preserve the life of the pregnant woman

II. Indications for legal abortion include threats to the pregnant woman's life and forcible rape

III. "Unlawful" or "unjustifiable" abortions are prohibited

IV. Abortions allowed when continuation of the pregnancy threatens the woman's life or health

V. American Law Institute Model Abortion Law: "A licensed physician is justified in terminating a pregnancy if he believes that there is substantial risk that continuance of the pregnancy would gravely impair the physical or mental health of the mother or that the child would be born with grave physical or mental defect, or that the pregnancy resulted from rape, incest or other felonious intercourse."

VI. Abortion law based on the May 1968 recommendations of the American College of Obstetricians and Gynecologists allows abortion when the pregnancy resulted from felonious intercourse, and when there is risk that continuance of the pregnancy would impair the physical or mental health of the mother. "In determining whether or not there is substantial risk (to the woman's physical or mental health), account may be taken of the mother's total environment, actual or reasonably foreseeable."

VII. No legal restriction on reasons for which an abortion may be obtained prior to viability of the fetus

VIII. Legal restrictions on reasons for which an abortion may be obtained were invalidated by court decision
Arizona, Connecticut, Florida, Idaho, Illinois, Indiana, Iowa, ${ }^{*}$ Kentucky, Louisiana, ${ }^{\dagger}$ Maine, Michigan, Minnesota, Missouri, Montana, Nebraska, Nevada, New Hampshire, North Dakota, Ohio, Oklahoma, Rhode Island, South Dakota, Tennessee, Utah, Vermont, West Virginia, Wyoming

Mississippi

Massachusetts, New Jersey, Pennsylvania

Alabama

Arkansas, California (does not include fetal deformity), Colorado, Delaware, Kansas, Maryland (does not include incest), New Mexico, North Carolina, South Carolina, Virginia

Oregon

Alaska, Hawaii, New York, Washington

District of Columbia, Georgia, Texas, Wisconsin ${ }^{\ddagger}$

* In State vs Dunklebarger, the Iowa statute, which is couched in terms of saving the life of the woman, has been interpreted to suggest that preservation of health is sufficient, $221 \mathrm{NW} 592$ (Iowa, 1928).

+ Although the Louisiana abortion statute does not contain an express exception to the "crime of abortion" the Louisiana Medical Practice Act authorizes the Medical Board to suspend or institute court proceedings to revoke a doctor's certificate to practice medicine in the state when the doctor has procured or aided or abetted in the procuring of an abortion "unless done for the relief of a woman whose life appears imperiled after due consultation with another licensed physician" (La Rev Stat Ann 37:1261).

The abortion laws of several other states have been ruled unconstitutional by lower state trial courts; however, these decisions are binding only in the jurisdiction in which the decision was rendered.

abortion laws in the District of Columbia and Illinois following court decisions rendered after January 1, 1971. On January 29, a three-judge Federal District Court in Chicago, ruling on the case of Mary Doe versus Illinois Attorney General Scott, found the Category-1-type Illinois abortion statute to be unconstitutionally vague and a violation of women's rights. ${ }^{1}$ That decision had the effect of revising Illinois law to allow legal abortion within the first 12 weeks of pregnancy if performed by a physician in a licensed hospital. However, Illinois' 97-year-old antiabortion law was restored on February 12 when US Supreme Court Justice Thurgood Marshall temporarily stayed the earlier lower court ruling, pending review of the case by the US Supreme Court. On April 12, 1971, the Supreme Court of the United States reversed a 1969 US District Court decision which had invalidated the 1901 abortion law for the District of Columbia. ${ }^{2}$ This action in effect reinstated the previous District of Columbia law, which, like the law in Alabama, allows abortion when necessary to preserve the life or health of a pregnant woman.

Case count data for legal abortion are available primarily from health departments in states that have instituted abortion reporting systems or, lacking that, from individual hospitals within a state. 


\begin{tabular}{|c|c|c|c|c|c|}
\hline \multirow[b]{2}{*}{ State } & \multirow[b]{2}{*}{$\begin{array}{l}\text { Frequency of } \\
\text { compilation of data }\end{array}$} & \multicolumn{4}{|c|}{ Source of data } \\
\hline & & $\begin{array}{l}\text { Individual abortion } \\
\text { reports sent by } \\
\text { physician or hospital } \\
\text { to health department }\end{array}$ & $\begin{array}{l}\text { Fetal death } \\
\text { certificates }\end{array}$ & Other & $\begin{array}{l}\text { No reporting } \\
\text { system }\end{array}$ \\
\hline Alaska & Bimonthly & $\sqrt{ }$ & & & \\
\hline Arkansas & & & & & $\sqrt{ }$ \\
\hline Delaware & Annually & $\sqrt{ }$ & & & \\
\hline Georgia & Monthly & $\sqrt{ }$ & & & \\
\hline Hawaii & Monthly & & $\sqrt{ }$ & $\checkmark$ & \\
\hline Kansas & Annually & $\sqrt{ }$ & & & \\
\hline Maryland & Quarterly & $\sqrt{ }$ & & & \\
\hline New Mexico & & & & & $\sqrt{ }$ \\
\hline South Carolina & Monthly & $\sqrt{ }$ & & & \\
\hline Virginia & Monthly & & $\sqrt{ }$ & & \\
\hline Washington & Monthly & $\sqrt{ }$ & & & \\
\hline
\end{tabular}

* Beginning April 1, 1971, hospitals in California will report only numbers of abortions performed and numbers of deaths associated with legal abortions.

${ }^{\dagger}$ In addition to reporting abortions on fetal death certificates sent to the state health department, hospitals in Hawaii voluntarily send case reports to the University of Hawaii School of Public Health, which was requested by the state legislature to study abortion practices in the state.

‡ Pregnancies aborted before the 16th week of gestation are reported to the health department on a "Certificate of Termination of Pregnancy"; those aborted during or after the 16 th week are reported on an abridged fetal death certificate. New York City hospitals also submit a weekly report of abortions performed, by method used and length of gestation.

Hospitals are asked but not required to submit case reports on abortions to the Committee on Maternal Health of the Medical Society of the State of North Carolina for compilation and analysis.

Statewide abortion reporting systems exist in only 14 of the 21 states which allow abortion in some situations other than when necessary to preserve the woman's life. Table 2 summarizes the status of abortion reporting in the 16 states that have passed new abortion laws since 1967 , showing the source of data and the frequency with which each state compiles its statistics. Arkansas and New Mexico were the only two of these 16 states without a statewide abortion reporting system in effect for 1970. Many of the new abortion laws enacted since 1967 require that a record be filed with the state health department within a specified time after an abortion is performed. Such provisions should be written into law if officials in the state want to obtain complete data. Although five states currently take their abortion data from fetal death certificates, these forms are designed primarily to obtain information on spontaneous fetal loss, and usually do not provide space for all of the data appropriate for cases of induced abortion. Fetal death certificates could not be used as a source of abortion data in many states where reporting of fetal deaths is not required if fetal loss occurs before the 16th week of gestation.

Accurate abortion statistics are not available for most states where abortions are performed under laws passed prior to 1967 or where the law has been invalidated by judicial decision. However, Massachusetts and the District of Columbia are both currently trying to develop systems of collecting abortion data in their jurisdictions.

\section{Statistics}

We estimate that more than 200,000 legal abortions were performed in the United States in 1970; more than 180,000 were reported to CDC by health departments and hospitals in 19 states and the District of Columbia. Table 3 shows the number of reported abortions and the ratio of legal abortions to 1000 live births for 11 states, which, all together, reported 
166,287 abortions. Abortion ratios for five states that enacted new abortion legislation during 1970 are calculated only from the date each new law became effective. An additional 13,000 abortions were reported to us by hospitals in states that do not require reporting or by states without complete data available for 1970.

State abortion ratios (abortions per 1000 live births) ranged from a high of 534 in New York to a low of 7 in Georgia (Table 3). With the exception of New

Table 3. Reported Legal Abortion Ratios Selected States, 1970

\begin{tabular}{|c|c|c|c|c|}
\hline State & Months* & Abortions $^{\dagger}$ & Live births & $\begin{array}{l}\text { Abortions } \\
\text { per } 1000 \\
\text { live births }\end{array}$ \\
\hline Alaska & 5 & 408 & 3,390 & 120 \\
\hline California & 12 & 62,672 & 364,007 & 172 \\
\hline Colorado & 12 & 2,263 & 42,758 & 53 \\
\hline Delaware & 12 & 560 & 10,234 & 55 \\
\hline Georgia & 12 & 705 & 96,069 & 7 \\
\hline Hawaii & $9 \frac{1}{2}$ & 2,741 & 13,364 & 204 \\
\hline New York & 6 & 87,530 & 163,847 & 534 \\
\hline North Carolina & 12 & 1,293 & 98,755 & 13 \\
\hline Oregon & 12 & 7,196 & 36,167 & 199 \\
\hline South Carolina & 11 & 392 & 43,306 & 8 \\
\hline Washington & 1 & 527 & 6,345 & 83 \\
\hline Total & & 166,287 & 878,242 & 189 \\
\hline
\end{tabular}

York, every state with a ratio of 100 or greater is on the Pacific Coast. Washington is the only west coast state with a ratio of less than 100 . Washington's ratio of 83 abortions per 1000 live births reflects only one month's experience with their new abortion law, which became effective on December 3, 1970. All those states with ratios of less than 15 abortions per 1000 live births are in the southeast part of the country. Colorado and Delaware, which are neither in the southeast or on the west coast, fall into a middle range with ratios of 53 and 55 .

Although the ratios in Table 3 compare abortions and live births in the same state within a given period of time, they do not necessarily indicate the ratio of abortions to live births for women living in those states. More than 36,000 women from other states had abortions in New York in the first 6 months of 1970. Since the New York State abortion law went into effect on July 1, New York has become the major source of legal abortion services not only for its own residents but also for women from many other states east of the Mississippi River. The New York law allows abortion for any woman through the twentyfourth week of pregnancy if performed by a licensed physician. There are no residency restrictions, and abortions do not have to be performed in a hospital. ${ }^{3}$ With the advent of this law in New York State, the great need for legal abortion services, previously unmet in most parts of the country, became evident as thousands of women traveled to New York in search of safe and legal abortions. Therefore, to estimate the legal abortion ratio for women who live in any state, one must know not only how many abortions were performed in the state, but also how many women from that state obtained abortions somewhere else. Figures 1 and 2 show reported legal abortion ratios for residents of each state for the last 6 months of 1970. The white bars represent abortions performed on residents in state; the blue bars represent abortions (per 1000 live births) performed out-of-state on residents of the state. Of the 16 states with new abortion laws, only California, Colorado, Kansas, Maryland, New Mexico, and New York allow abortions for out-of-state women, and residency data were available for only four of these states. The proportion of abortions performed on non-residents was reported to be 6.5 percent in California, 8 percent in Colorado, 3 percent in Maryland, 25.3 percent in Upstate New York, and 51.4 percent in New York City. The abortion ratios for these states in Figure 1 have been adjusted to allow for abortions performed on women from other states. However, for the other states we have had to assume that all reported abortions were performed on residents. State of residence is known for out-of-state women who received abortions in Colorado and New York. More than 36,000 abortions performed on non-residents in these locations are the basis for the out-of-state abortion ratios represented in blue.

In Figure 1 the states are organized by geographical regions. While there is wide disparity between abortion ratios of the 50 states, greater similarity exists between states within each geographical region. The Middle Atlantic region has the highest overall 
Abortions per 1000 Live Births

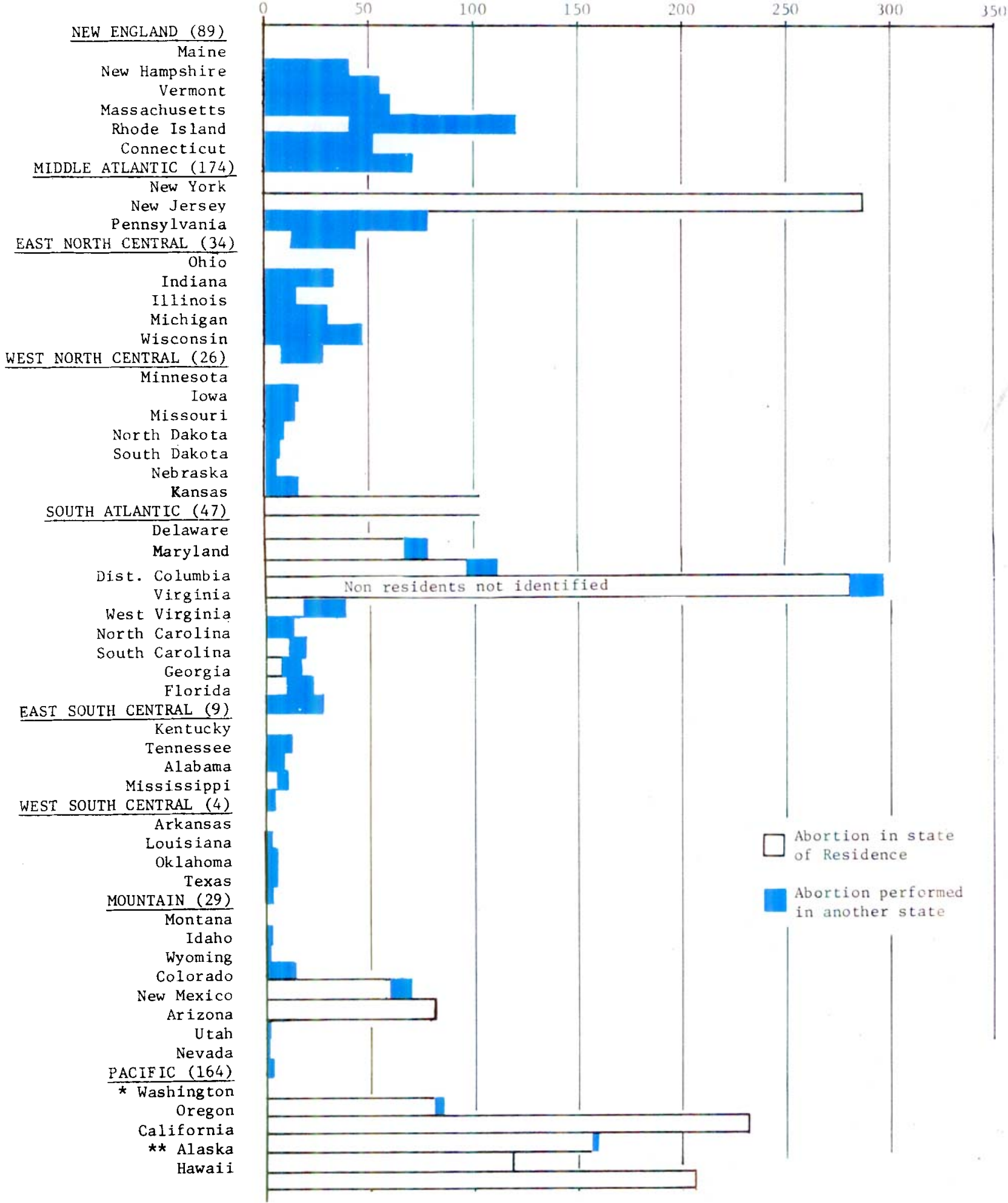

Figure 1. Ratios of reported legal abortions to live births by state of residence on geographic order-July-December 1970 . ${ }^{*}$ December 3December 31,$1970 ;{ }^{*}$ "July 29-December 31,1970 ; ( ) ratio for region. 
ratio (174), with almost all abortions obtained by women from each state in that region having been performed in New York. The in-state abortion ratio for Pennsylvania, however, is based on data from only four hospitals. More complete reporting from Pennsylvania would certainly increase the in-state portion of the abortion ratio for that state.

The Pacific region is second highest, with a ratio of 164 abortions per 1000 live births, and it is the only area where virtually all reported abortions were in each woman's home state. These are the only five states in the country with an out-of-state abortion ratio less than 0.5 -a figure too small to show in these graphs. It is of interest that in Canada the Pacific Coast province of British Columbia had that nation's highest abortion ratio ( 82 abortions per 1000 live births in 1970), compared to the abortion ratio of 30 reported for the nation as a whole. ${ }^{4}$

The third highest ratio is found among the four northern-most states listed under the South Atlantic region-Delaware, Maryland, the District of Columbia and Virginia. The collective ratio of these four jurisdictions is 103. They are followed by the New England states with a regional ratio of 89 . Except for Massachusetts, all abortions reported for women from the New England states were performed in New York.

Ratios for the other regions decrease in proportion to their distance from New York and as they become less urban. This is consistent with Pott's conclusion, based on data from many countries, that the incidence of induced abortion is always higher in urban areas. ${ }^{5}$ Colorado, Kansas, and New Mexico stand out in their respective regions as the only states in each area with an updated abortion law.

Figure 2 shows the same in-state and total abortion ratios by state of residence listed in rank order. The District of Columbia is first, with an abortion ratio of 296. Washington, DC, was the first jurisdiction to have its abortion law invalidated by judicial decision, and it appears to be the only place where court action resulted in a large increase of reported legal abortions. It is of interest that while more than 87,000 abortions were performed in New York State during this 6 months, compared with an estimate of less than 4,000 abortions performed in Washington, the District's incity abortion ratio was higher than that for New York State. Two factors have operated to somewhat artificially inflate the ratio for the District of Columbia. First, although the residency of women who received abortions there was not reported, it can be assumed that the ratio would be smaller if abortions performed on non-District residents had been subtracted from the total, as was done for New York. Secondly, the District's ratio is higher than that for New York State

Table 4. Legal Abortions by Age-Selected States, 1970

\begin{tabular}{|c|c|c|c|c|c|c|c|c|c|c|c|c|c|c|c|c|c|c|}
\hline State & \multicolumn{2}{|c|}{$<15$} & \multicolumn{2}{|c|}{$15-19$} & \multicolumn{2}{|c|}{$20-24$} & \multicolumn{2}{|c|}{$25-29$} & \multicolumn{2}{|c|}{$30-34$} & \multicolumn{2}{|c|}{$35-39$} & \multicolumn{2}{|c|}{$\geq 40$} & \multicolumn{2}{|c|}{ Unknown } & \multicolumn{2}{|c|}{ Total } \\
\hline Colorado & 61 & 2.7 & 695 & 30.7 & 697 & 30.8 & 364 & 16.1 & 214 & 9.5 & 226 & $\dagger 10.0$ & 一 & - & 6 & 0.3 & 2263 & 100.0 \\
\hline Delaware & 19 & 3.4 & 155 & 27.7 & 155 & 27.7 & 82 & 14.6 & 74 & 13.2 & 50 & 8.9 & 25 & 4.5 & 0 & 0.0 & 560 & 100.0 \\
\hline Georgia & 32 & 4.5 & 173 & 24.5 & 159 & 22.6 & 152 & 21.6 & 89 & 12.6 & 68 & 9.6 & 32 & 4.5 & 0 & 0.0 & 705 & 100.0 \\
\hline Hawaii ${ }^{*}$ & 19 & 0.7 & 526 & 19.2 & 1079 & 39.4 & 537 & 19.6 & 281 & 10.3 & 190 & 6.9 & 101 & 3.7 & 8 & 0.3 & 2741 & 100.0 \\
\hline New York & 138 & 0.7 & 4490 & 24.2 & 6262 & 33.8 & 3218 & 17.4 & 2102 & 11.3 & 1554 & 8.4 & 661 & 3.6 & 110 & 0.6 & 18535 & 100.0 \\
\hline Oregon & 100 & 1.4 & 2396 & 33.3 & 2562 & 35.6 & 977 & 13.6 & 611 & 8.5 & 374 & 5.2 & 176 & 2.4 & 0 & 0.0 & 7196 & 100.0 \\
\hline South Carolina & 6 & 1.5 & 110 & 28.1 & 112 & 28.6 & 62 & 15.8 & 47 & 12.0 & 26 & 6.6 & 29 & 7.4 & 0 & 0.0 & 392 & 100.0 \\
\hline Total & 505 & 0.7 & 18155 & 23.7 & 27404 & 35.7 & 13772 & 17.9 & 8479 & 11.1 & 5737 & 7.5 & 2294 & 3.0 & 395 & 0.5 & 76759 & 100.0 \\
\hline
\end{tabular}

* July 29-December 31 ; provisional data.

+ Abortions performed on women 35 or older.

¥ March 13-December 31, 1970.

Represents only abortions reported by certificates filed with the New York City Health Department; delayed filing of certificates results in incomplete data on age; July-December.

|| New York State exclusive of New York City, July-December.

\& February-December. 


\section{Abortions per 1000 Live Births}

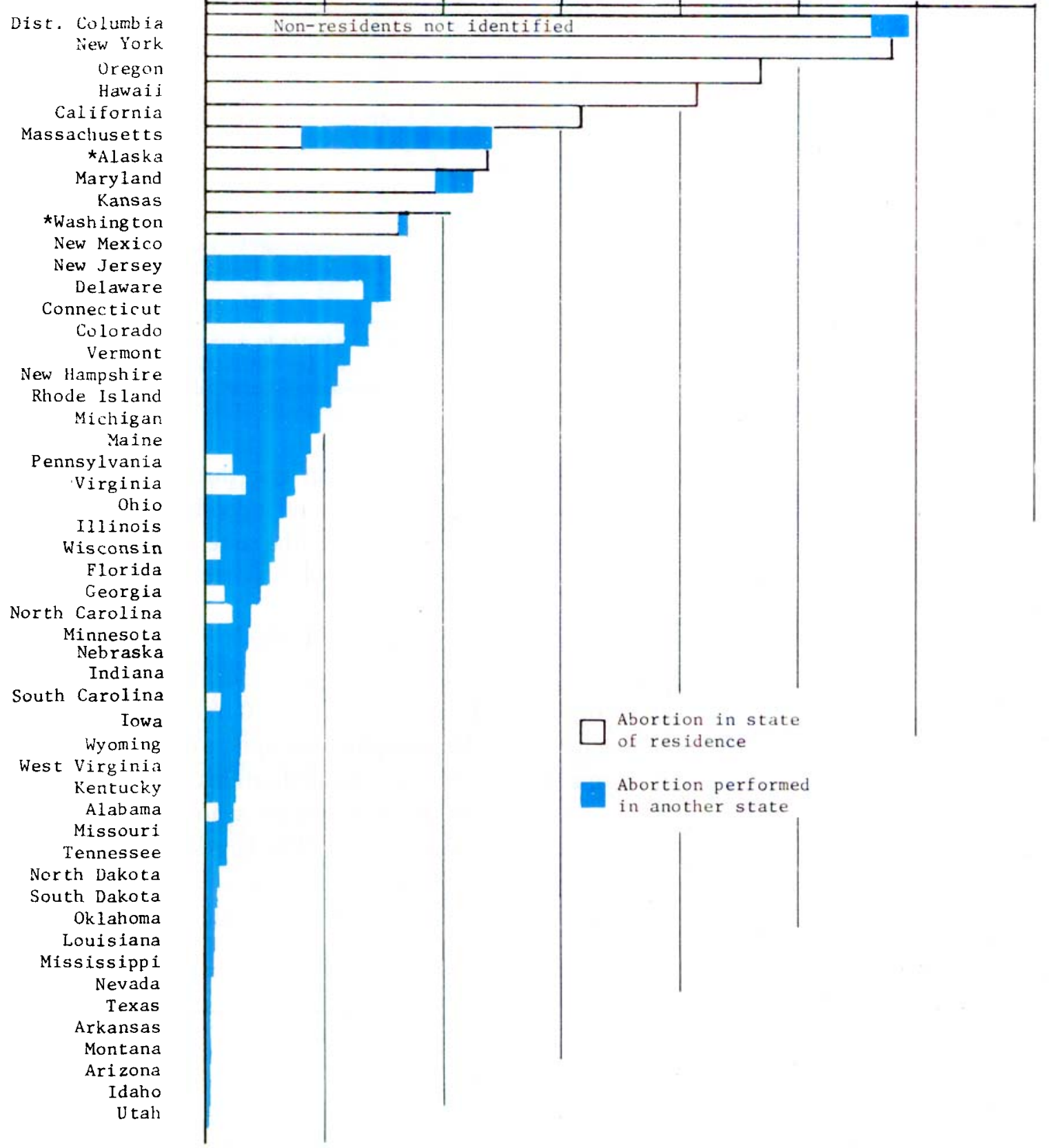

Figure 2. Ratios of reported legal abortions to live births by state of residence in rank order-July-December 1970. *Alaska, July 21December 31, 1970; Washington, December 3-December 31, 1970.

because it is a city rather than a state. Most abortions are performed in cities; as a result, large cities usually have a much higher abortion ratio than the state of which they are a part. For instance, the ratio for New York City, excluding non-New York State residents, is 434, compared with 160 for Upstate New York and 289 for the state as a whole. In Washington, DC, there is no large rural and suburban area with live births to dilute the large metropolitan area's abortion ratio.

With the exception of the District of Columbia and Massachusetts, each of the first 11 states in Figure 2 have passed new abortion laws since 1967. The five states with the least restrictive laws (Alaska, Hawaii, New York, Washington and Oregon) are all ranked 
Table 5. Age-Specific Legal Abortion Ratios ${ }^{*}$-Selected States, 1970

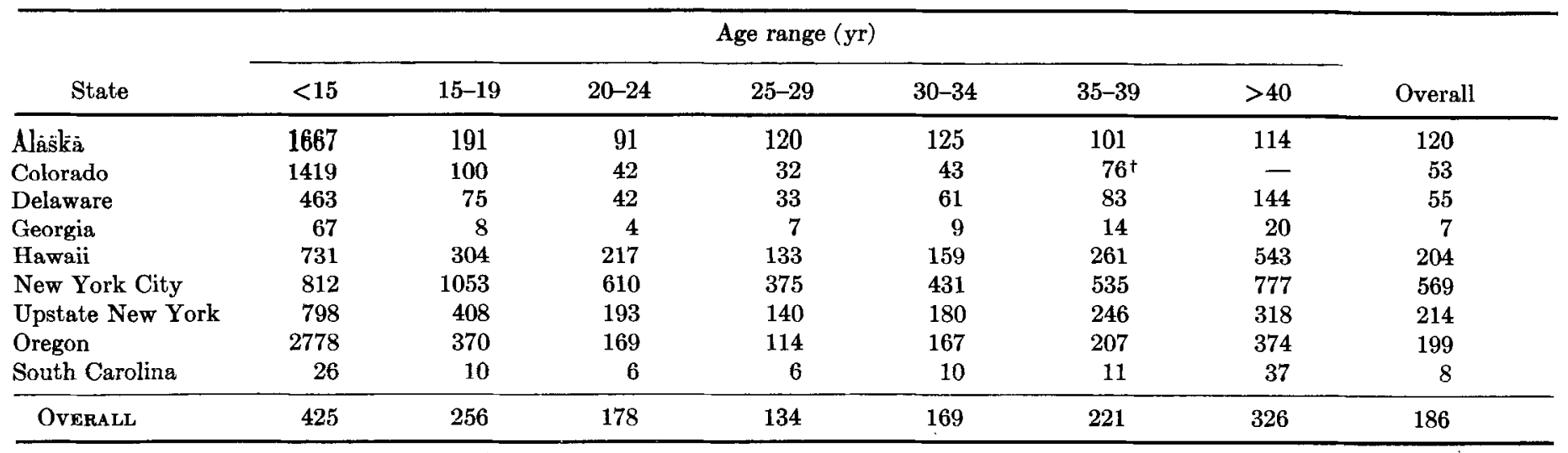

* Calculated as the number of legal abortions in women of a given age group per 1000 live births to women of the same age group. Sources of data are Table 2 of this report for abortions by age and Table 1 for total 1970 live births. Age distribution of live births based on 1967 Vital Statistics of the United States, 1969 Georgia Vital and Morbidity Statistics, and 1969 Maryland Annual Vital Statistics Report.

+ Colorado reports oldest age group as $\geq 35$.

in the top 10 , showing that this kind of law has a significant effect on abortion practice. However, states with laws similar to the American Law Institute (ALI) Model Penal Code on abortion, listed in Category 5 in Table 1 , are distributed in this rank order between 5 and 47 . Women residing in 10 states with Category 1 abortion laws obtained more legal abortions per 1000 live births than women from Georgia, South Carolina, and North Carolina, all of which have Category 5 (ALI-type) laws. Although Georgia is the only state with an ALI abortion law that has been further liberalized by court decision, more abortions were performed on Georgia women in New York than in Georgia. Considering both Figures 1 and 2, it appears that at least three factors affect the overall abortion ratios of individual states: (a) the status of abortion law in the state, (b) regional characteristics, and (c) the state's proximity to New York.

\section{Demographic Analysis}

The second aspect of our study of abortions in the United States in 1970 has been an attempt to obtain a demographic description of the population of women who have legal abortions. Table 4 shows the age distribution of women who had legal abortions in nine states in 1970 . The largest proportion $(35.7 \%)$ were obtained by women age 20 to 24 , the next largest group being women age 15-20. Only 22 percent of

Table 6. Legal Abortions by Material Status-Selected States, 1970

\begin{tabular}{|c|c|c|c|c|c|c|c|c|}
\hline \multirow[b]{3}{*}{ State } & \multicolumn{6}{|c|}{ Marital status } & & \\
\hline & \multicolumn{2}{|c|}{ Married } & \multicolumn{2}{|c|}{ Unmarried* } & \multicolumn{2}{|c|}{ Unknown } & \multicolumn{2}{|c|}{ Total } \\
\hline & No. & $\%$ & No. & $\%$ & No. & $\%$ & No. & $\%$ \\
\hline Alaska $^{\dagger}$ & 157 & 38.5 & 249 & 61.0 & 2 & 0.5 & 408 & 100.0 \\
\hline Delaware & 169 & 30.2 & 391 & 69.8 & 0 & 0.0 & 560 & 100.0 \\
\hline Georgia & 308 & 43.7 & 397 & 56.3 & 0 & 0.0 & 705 & 100.0 \\
\hline Maryland ${ }^{\ddagger}$ & 1015 & 31.6 & 2182 & 68.0 & 13 & 0.4 & 3210 & 100.0 \\
\hline Upstate New York & 6894 & 37.2 & 11641 & 62.8 & $\mathbf{0}$ & 0.0 & 18535 & 100.0 \\
\hline Oregon & 1655 & 23.0 & 5541 & 77.0 & 0 & 0.0 & 7196 & 100.0 \\
\hline South Carolinal| & 146 & 37.2 & 246 & 62.8 & 0 & 0.0 & 392 & 100.0 \\
\hline Total & 10344 & 33.4 & 20647 & 66.6 & 15 & 0.0 & 31006 & 100.0 \\
\hline
\end{tabular}

* Unmarried includes women who are separated, widowed or divorced and women who have never married.

+ Provisional figures, July 29-December 31.

† July-December.

New York State, exclusive of New York City, July-December.

II February-December. 
Table 7. Legal Abortion Ratios $*$ by Race Selected States, ${ }^{\dagger} 1970$

\begin{tabular}{lrrccc}
\hline & \multicolumn{5}{c}{ Katı } \\
\cline { 2 - 5 } \multicolumn{1}{c}{ State } & White & Black & "Other" races & White/Black \\
\hline Alaska & 141 & 185 & 65 & 0.8 \\
Delaware & 56 & & $48^{5}$ & & $1.2 \|$ \\
Georgia & 9 & 4 & - & 2.2 \\
Hawaii" & 322 & 110 & 154 & 2.9 \\
Maryland** & 86 & 154 & 88 & 0.6 \\
South Carolina & 12 & 3 & - & 4.0 \\
\hline
\end{tabular}

* Ratios calculated as the number of race-specific abortions per 1000 race-specific live births, racial distribution of live births based on 1967 Vital Statistics of the US.

** July-December.

+ All states with data available.

\$ July 29-December 31 .

"Includes Black and "Other" (live births and abortions).

|| White abortions per 1000 live births/Black and "other" abortions per 1000 live births.

II March 11-December 31.

- Not calculated because small number of abortions in this category tends to distort the ratio.

the women were 30 or older, and less than 1 percent were younger than 15 . However, in Table 5 , where the number of abortions is compared with the number of live births in each age group, girls less than 15 and women 40 or more years old have the highest abortion ratios. Data from seven states, in Table 6, show that 66.6 percent of the women were not married at the time of abortion.

Table 7 presents white and black race-specific legal abortion ratios for six states. The abortion ratio for white women is higher than for black in each state except Alaska and Maryland. In South Carolina pregnant white women had their pregnancies ended by legal abortion at a rate four times greater than that of pregnant black women in the same state.

\section{Morbidity and Mortality in New York City}

The third major part of the abortion work at CDC has been an ongoing epidemiologic study of morbidity and mortality from induced abortion in New York City. Figure 3 shows reported deaths from induced abortion in New York City for 1970. Eleven deaths from illegal abortions were reported in the first half of 1970 , before the new law went into effect, compared with six illegal abortion deaths in the last 6 months of the year. A cluster of both legal and illegal abortion deaths occurred in July, August, and September with only three legal and no illegal abortion deaths between October 1 and the end of the year.

Eight deaths were attributed to legal abortions during the first 6 months under the new law; five of the eight occurred during the month of July. The health care delivery system in New York City was inexperienced in the provision of abortion services and was, in many ways, unprepared to cope with the vast numbers of local and non-resident women requesting abortions in New York during the first few months the law was in effect. Therefore, it was not unexpected that mortality and morbidity would be higher during this initial period.

Of the 8 deaths associated with legal New York City abortions in 1970, 3 followed abortion by hysterotomy, 1 followed replacement of amniotic fluid with hypertonic saline, and 4 followed dilatation and curettage. Three of the women who died had underlying medical conditions that contributed to death.

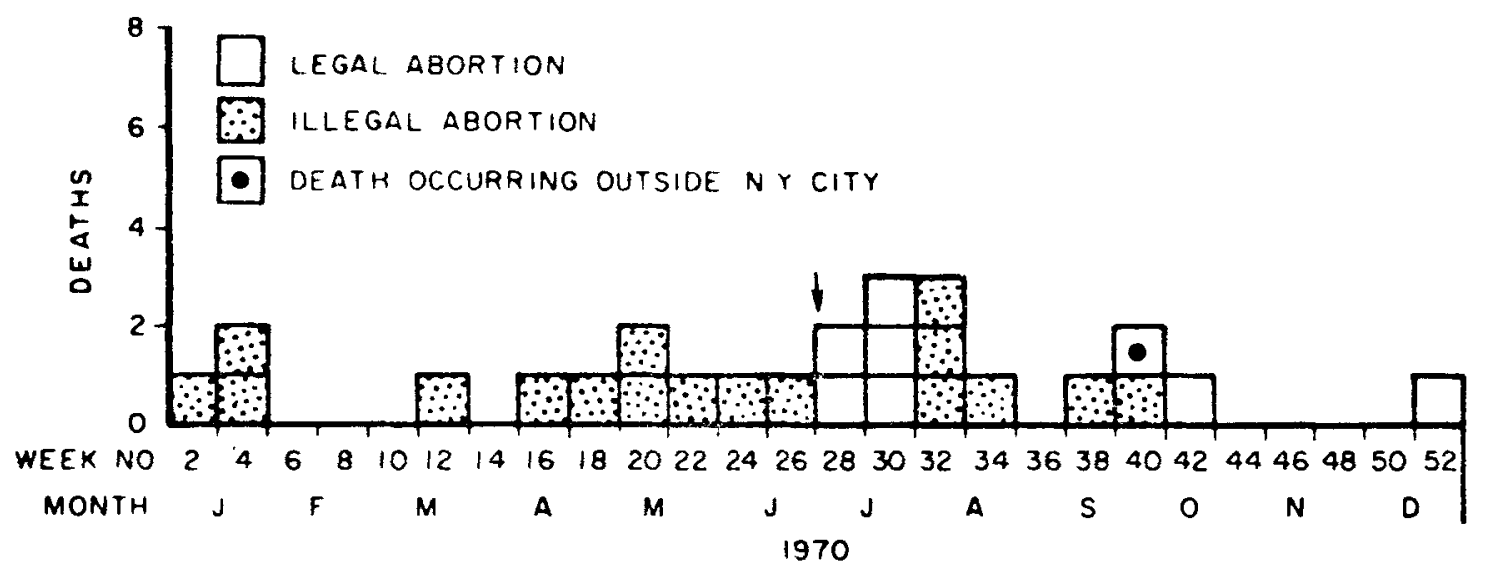

Figure 3. Induced abortion deaths in New York City. 
Table 8. Adjusted Uterine Perforation Rate by Length of Gestation for Abortions Performed by a Single PhysicianNew York City, July 1, 1970-January 13, 1971

\begin{tabular}{cccc}
\hline $\begin{array}{l}\text { Length of gestation } \\
\text { (menstrual weeks) }\end{array}$ & Abortions & Perforations & $\begin{array}{c}\text { Rate per } 1000 \\
\text { abortions }\end{array}$ \\
\hline 8 or less & 468 & 0 & 0.0 \\
$9-10$ & 585 & 0 & 0.0 \\
$11-12$ & 520 & 2 & 3.8 \\
$13-14$ & 64 & 1 & 15.6 \\
15 or more & 31 & 3 & 96.8 \\
\hline Toт^L & 1668 & 6 & 3.6 \\
\hline
\end{tabular}

Of the 4 deaths associated with dilatation and curettage, 3 resulted from perforation of the uterus. Two of these deaths occurred after a D and C performed with a sharp curet on women who were more than 12 weeks pregnant.

Further evidence for an association between advanced pregnancy and mortality from $D$ and $C$ was obtained from an epidemiologic investigation of 6 cases of uterine perforation related to abortions performed by one New York City physician. All 6 patients were hospitalized, 5 had exploratory laparotomy, and 3 of these had hysterectomy; 1 woman died. Although this physician had estimated the length of pregnancy at between 10 and 12 weeks in all 6 cases, when it was calculated by date of last menstrual period, 4 of the women were beyond 12 weeks, and all 6 cases were at least 11 weeks pregnant. It appears from these cases that accurate clinical assessment of the duration of pregnancy is a critical factor, especially at the 10-to-12-week period. For this physician, the overall rate for abortions performed at 12 or fewer weeks was 1.3 uterine perforations per 1000 abortions, while for pregnancies of more than 12 weeks the perforation rate was 42.1 (Table 8).

Legal abortion mortality rates in other countries

Table 9. Iegal Abortion Case Fatality Rate by Length of Gestation-New York City, July 1, 1970-January 31, 1971

\begin{tabular}{cccc}
\hline & \multicolumn{3}{c}{ Abortions } \\
\cline { 2 - 4 } $\begin{array}{c}\text { Length of gestation } \\
\text { (weeks) }\end{array}$ & Number & Deaths & $\frac{\text { Case fatality }}{100,000}$ \\
\hline 12 or less & 59,024 & 4 & 6.8 \\
More than 12 & 23,542 & 5 & 21.2 \\
\hline Total & 82,566 & 9 & 10.9 \\
\hline
\end{tabular}

range from 0.6 deaths per 100,000 abortions in Hungary to 41.1 deaths per 100,000 abortions in Denmark. This rate for 7 months in New York City was 10.9, which is higher than legal abortion mortality rates reported for Japan and Hungary, but lower than for Denmark, Sweden, England, and Wales.

Grouping New York City abortions and abortion deaths into two categories according to whether the abortion was performed before or after the end of the 12 th menstrual week of gestation results in a mortality rate which is more than three times higher for abortions performed after the 12th week (Table 9). In the 7-month period between July 1, 1970, and January 31,1971 , the mortality rate was 6.8 for abortions performed before the end of the 12th week and 21.2 for abortions performed later.

\section{Summary}

We estimate that more than 200,000 legal abortions were performed in the United States during 1970, approximately 36,000 of which were performed on nonresidents in New York State. The impact of the New York abortion law of July 1970 is of such significance that one cannot estimate abortion practices of women in the other states without taking their out-of-state abortions into account. The abortion ratio for women residents of any state appears related not only to abortion law in the state, but also to what region of the country the state is in and how close it is to New York.

A demographic description of women who received abortions in several states show that the majority were between 14 and 25 years of age, white, and unmarried. Despite this, abortion is more prevalent among pregnant women at the extremes of the child-bearing age span.

The incidence of death from both legal and illegal induced abortion was high in New York City during the first few months under their new law, but mortality dropped sharply after October 1 . The overall death rate for legal abortion in New York City was 10.9 per 100,000 abortions during the first 7 months, a rate which falls in a middle range among legal abortion mortality rates reported from other countries. Mortality was more than three times higher for abortions after the 12th week of pregnancy. Uterine perforation and mortality from abortion can probably be 
reduced by limiting the $\mathrm{D}$ and $\mathrm{C}$ method to pregnancies of not more than 12 menstrual weeks.

NOTE: CDC maintains surveillance of mortality and morbidity resulting from legally induced abortions performed in states outside the women's state of residence. Any fatality or hospitalization of a patient for complications subsequent to an abortion performed out-of-state should be reported by collect telegram to Center for Disease Control, Attention: Family Planning Evaluation Activity, Atlanta, Georgia 30333.

\section{References}

1. Doe vs Scott (N.D. Ill. 1971).

2. U.S. vs Vuitch (305 F. Suppl. 1302 (D.D.C. 1969), 90 S. Ct. 1497 (1970).

3. New York Penal Law. L.1970 C. 127.

4. Dominion Bureau of Statistics.

5. Potts DM: Post contraceptive control of fertility. Int J Gynaecol Obstet 8:959, 1970.

\section{Acknowledgments}

We wish to acknowledge the following organizations and individuals whose contributions made this report possible.

Bataan Memorial Hospital, Albuquerque, New Mexico; Clayton T. Beecham, MD: Director, Gynecology-Obstetrics, The
Geisinger Medical Center, Danville, Pennsylvania; Thomas A. Burch, MD, MPH: Chief, Research and Statistics Office, Hawaii State Department of Health; Bureau of Maternal and Child Health, California Department of Public Health; Donald J. Davids: Chief, Records and Statistics Section, Colorado State Department of Public Health; Maternal Health Division, District of Columbia Department of Human Resources; John P. Emich, Jr., MD: Administrative Chairman, Department of Obstetrics and Gynecology, Philadelphia General Hospital; Charles E. Flowers, Jr., MD: Chairman, Department of Obstetrics and Gynecology, The Medical Center, University of Alabama in Birmingham; Donald K. Freedman, MD: Director, Division of Public Health, Alaska Department of Health and Welfare; Walter P. Gust, Director, Bureau of Family Planning, Commonwealth of Virginia Department of Health; S. Leon Israel, MD: Chief, Obstetrics and Gynecology, Pennsylvania Hospital, Philadelphia, Pennsylvania; Selig H. Katz, MD: Director, Bureau of Maternal and Child Health and Family Planning, State of New York Department of Health; Carl J. Levinșon, MD: Chairman, Department of Obstetrics and Gynecology, Mr. Sinai Hospital, Milwaukee, Wisconsin; W. Joseph May, MD: Chairman, Committee on Maternal Health, Medical Society of the State of North Carolina; Catherine B. Middleton: Director, Maternal and Child Health, Delaware State Board of Health; Oregon State Board of Health; J. E. Padgett, Jr., MD: Chief, Bureau of Maternal and Child Care, South Carolina Board of Health; Jean Pakter, MD: Director, Bureau of Maternity Services and Family Planning, City of New York Department of Health; Ben M. Peckham, MD: Chairman, Department of Gynecology and Obstetrics, The University of Wisconsin Medical School; Patricia Schloesser, MD: Director, Maternal and Child Health, Kansas State Department of Health; Albert K. Schoenbucher, MD: Director, Maternal Health Service, Georgia Department of Public Health; J. King B.E. Seegar, MD: Chief, Maternal and Family Planning Section, Division of Maternal and Child Health, Maryland State Department of Health; William G. Slate, MB, ChB, MS: Chairman, Division of Obstetrics and Gynecology, Albert Einstein Medical Center, Philadelphia, Pennsylvania; Vital Statistics Section, Division of Health, Washington State Department of Social and Health Services.

Judith P. Bourne is Nurse Epidemiologist, Family

Planning Evaluation Activity, Epidemiology Program, Center for Disease Control, Atlanta, Georgia 30333.

Dr. Kabn formerly was EIS Abortion Surveillance Officer, Family Planning Evaluation Activity, Epidemiology

Program, Center for Disease Control. Presently, be is a Resident at Betb Israel Hospital, Boston, Massachusetts.

Dr. Conger formerly was EIS Epidemiologic Studies Officer, Family Planning Evaluation Activity, Epidemiology

Program, Center for Disease Control. Presently, be is a

Resident in Community Medicine, University of California Medical Center, Berkeley, California.

Dr. Tyler is Cbief, Family Planning Evaluation Activity, Epidemiology Program, Center for Disease Control, Atlanta, Georgia 30333. 